\title{
EXPLORING THE INTERCULTURAL IDENTITY OF SLOVAK-ROMA SCHOOLCHILDREN IN THE UK
}

\author{
Laura Hryniewicz, Jean-Marc Dewaele \\ Birkbeck, University of London \\ 26 Russell Square, WC1B 5DQ London, United Kingdom
}

\begin{abstract}
There is a significant body of literature about the Roma, but comparatively little exists in which their voices can be heard. This study takes an intercultural perspective to look at the identity negotiations of four self-identifying Roma-Slovak schoolchildren between the ages of 13-14 enrolled at a state academy in Kent. Interviews focused on the role of language in constructing their identities, the perceptions of others and the nature of possible conflicts. The qualitative analyses revealed five themes: Perception of Identity by Others, Adaptability, Aspirations, Self-Perceptions of Identity, and Conflict. Participants' identities were found to be far more dynamic than the traditional binarized view of the Roma as the 'other' (McGarry \& Agarin 2014). There is a strong element of ascription by others in terms of the nature of participants' ethnicity and its relationship to their identity. Both their ethnic and national identity are central in the ways in which they see themselves.
\end{abstract}

Keywords: identity construction, intercultural, Slovak-Roma, UK, schoolchildren, qualitative study

\section{INTRODUCTION}

The negotiation between cultural identities is an increasingly widespread concern in contemporary society. Taking a performance narrative inquiry approach, O’Neill (2013) argues that today 'there is an increasing need for people to navigate linguistic and cultural borders' (p. 397) and this has a significant impact on the ways in which identities are constructed, maintained and revised. She concludes that under globalised conditions people must work to move beyond misunderstandings of identity and to reject negative stereotyping. It seems that developments in technology have meant that our ability to communicate has increased exponentially, and yet with this comes an increasing need to try to make ourselves understood. These complex transactions, Sharma notes, 'have necessarily involved negotiation and renegotiation of identities, and forging relationships with people, places and cultures.' (2011: 352). Zhu (2010) suggests that the younger generation have the capacity to autonomously construct new cultural and social identities through interactions, and that through language socialisation they have the capacity to actively bring about changes within their own communities. The aim of this study is to contribute to this emerging area of interest through semi-structured interviews with four Slovak Roma schoolchildren living in Medway.

\section{LITERATURE REVIEW}

An essentialist view of identity traditionally links the formation and maintenance of identity with a geographical place, in particular a specific country in which a particular language is spoken (Holliday et al. 2004). To ask where someone is from can be seen 
as a way to measure cultural difference in a relational sense. Omoniyi highlights that borders have a clear relationship to the management of 'in-group and out-group identities' (2010: 123) which shows, at least historically, the way that the demarcation of a territory has been an indicator of identity; one could expect to encounter, within those bounds, a group of ideologically similar individuals. Similarly, Extra (2010) considers nationality as a collection of attributes shared by a distinct community which does not necessitate blood lineage and is in some way at least influenced by the geographical boundaries of a nation. However, a key feature of contemporary society is the de-territorialisation of communities (Leung et al. 2009) leading to questions about demarcation of identity. Within this debate Edwards (2009) draws attention to the concept of 'boundaries' suggesting that they provide a more enduring demarcation of identity which allows groups to prevail over long periods of time. However, as a greater number of people cross geographical boundaries, the question arises; what is the nature of the boundaries which are created and what are the implications for the maintenance or negotiation of identities?

The larger context for this study is the rise in global and transnational migration; specifically the European Union which allows free movement of EU nationals for labour purposes as per Article 45 (European Union 2014). Although it might end soon, it facilitated both mobility and migration (Huysmans 2006), resulting in both cultural pluralism through transitory economic mobility, and multiculturalism through the increased interaction of cultural groups making more permanent economic migrations. Under these conditions, there is a propensity to label individuals based on their geographical origins. However, despite Smith's observation that 'national identity is perhaps the most fundamental and inclusive (1999: 143), and Tracy's (2002) categorisation of national identity as a 'Master Identity' it appears that under contemporary conditions the idea of where you are 'originally from' and therefore who you are, or are seen to be, is becoming less and less straightforward. As McGuigan states, we now live in a global 'community of communities' (2012: 58) and, building on Hall's (1992) ideas about the fragmentation or multiplicity of identities, and Antaki and Widdicombe's (1998) emphasis on the agency of an individual in the construction of their identity, Burgarski considers that identity 'far from being a simple set of static givens, is now understood to be a highly complex, multi-layered and dynamic construct, whose many dimensions interact to constitute a variable whole (2012: 220). This is situated alongside warnings about the 'pervasiveness of the discourses of banal nationalism' (Piller 2011: 68) in which the tendency towards reductionist representations of national groups which emphasise homogeneity are still apparent, perhaps descended from the 'grand discourses which constitute the ideological construction of nationhood [which] continue to be significant in the social construction of social exclusion.' (Samers 1998: 123). The 2016 decision for Brexit proved how powerful the lure of nationalism remains in the UK.

One of the aims of the present study is to move away from grand discourses of identity and to take an intercultural approach to focus on the specific experiences of Slovak Roma school children in a specific area of Britain, taking into consideration the particularities of the negotiation of their identities within that setting. Such an increase in transnational movements can only lead to a greater number of more complex and less trans- 
parent interactions (Blommaert 2005) which are perhaps unlikely to adhere to previous models of identity and interaction. Within this particular context Levinson and Hooley (2013: 13) point out that sometimes 'it is all too easy to acknowledge the heterogeneity of and fluidity of mainstream cultures, while viewing minority cultures as if they were both homogenous and static.' Paradoxically, it is often the minority culture which must demonstrate the most adaptability in order to assimilate into the norms of a larger culture.

One key area for concern is the question of how identity can be negotiated in a multilingual society, through linguistic practices, when some language forms carry significantly less prestige and value. Although the significance of national identity under contemporary global conditions has been called into question, there remains specific interest is the ways in which language and national identity are related. Language differences, according to Gumperz (1982: 6-7) 'play an important, positive role in signalling information as well as creating and maintaining the subtle boundaries of power, status, role and occupational specialization that make up the fabric of our social life. Migration is one of the key sites of identity negotiation, and whilst fluidity is a feature of this, there is also an element of struggle as an immigrant 'grapples with his or her place in the larger structures' (Bhatia \& Ram 2009: 148). Diasporic communities have a number of challenges to face; in particular the negotiation of how far they preserve their traditional cultural practices and traditions, and how far they forge new identities for themselves in their new setting.

Feldman, Stone and Renderer (1990) pointed out that using a non-English language in an English-speaking country can result in discrimination, negative stereotypes and a range of other disadvantages for speakers, and that there is a clear expectation for those who are considered to occupy a subordinate position in society to converge to dominant linguistic norms. However Marlow and Giles (2010) found that speakers were also subject to in-group criticism when they elected to speak English rather than their mother tongue, raising interesting questions regarding the nature of conflict and the formation of identity within these language negotiations.

There is growing interest in the notion that individuals may be different in each of their languages. Previous studies (Pavlenko 2006; Koven 2007; Dewaele \& Nakano 2012; Dewaele 2016, Panicacci \& Dewaele 2017) have specifically addressed this emergent phenomenon. Koven (2007: 239) demonstrated that bilinguals used 'different speaker role perspectives' when telling stories in their two different languages and argued that this was the result of the persona the speaker felt able to adopt in each language, which suggests that the act of speaking a language influences our own perceptions of who we can and should be. Dewaele (2010) alludes to this when he suggests that the connotations of a language may be transferred to a speaker's self-perception when communicating. However, he also cautions that this is not a case of personality change, but an adjustment in the speaker's observed performance.

\section{ROMA IDENTITY IN CONTEXT}

The name 'Roma' itself presents a number of difficulties in terms of its usage. In the Romani language its denotation is a plural noun meaning 'people' (Miskovic 2009: 203). However, in western discourse the term is often conflated with 'Gypsy', both of which 
work on an almost purely connotational level, acquiring pejorative meanings which 'exist in other people's mouths, serving other people's intentions' (Bahktin, in Hall, 1992: 235). Schneeweis feels that 'the meanings associated with Gypsy and Roma are deployed and put to uses that fix such meanings into "truths"' (2012: 676), suggesting a construction of identity which may not match the fabric of reality. Scollon and Scollon (2012: 271) caution against contexts in which one aspect of identity is 'singled out for emphasis, given a positive or negative value, or treated as a full description of a "culture" or a person'; furthermore this approach, as Zhu points out, denies the multiplicity and complexity of identity and alerts us to the ways in which we see ourselves, and how we are seen, may be divergent (2014: 201). In the case of the discourses surrounding the Roma, what begins to emerge is the role of others in constructing representations of Roma identity, that which McGarry (2010) suggests is the 'unwanted other'. There appears to have been an absence of opportunity for members of this culture to contribute actively to these discourses, something which this study hopes to begin to redress.

As Zhu (2014) points out, the concept of 'cultural identity' is an extremely difficult one with which to deal. In the case of the Roma, the question of 'who they really are' has been the subject of a number of studies (see McGarry \& Agarin 2014; Levinson 2014). In an early attempt to differentiate between the various travelling subcultures, Vesey-Fitzgerald (1973) makes a clear distinction between Roma and Irish Travellers as two groups with markedly different attributes. Whilst this broad distinction still holds, evidenced by the Ethnicity Codes in use today in the UK, the term 'Roma' is used almost arbitrarily interchangeably with terms such as 'Gypsy' which is widely seen to be politically incorrect (Hancock 2002). European policy documents state that the term "Roma" is commonly used as an umbrella term encompassing other groups such as Gypsies, Travellers and Sinti, and GRT (Gypsy/Roma/Traveller) is currently the term used in UK policy documents (Levinson 2014) to represent communities which, although may be seen as similar, actually have quite distinctive origins, histories and cultural practices. To conflate these is surely an obfuscation of any inquiry into identity and yet, despite attempts to move away from it, this conflation perpetuates even in very contemporary writing. Murray points out the problematic nature of this political nomenclature in that an umbrella term "can assume a hierarchy (i.e. Travellers seen as a subgroup of Roma)" and that "if you are not named you can be excluded and marginalised within the very category in which you are identified" (2012: 570). It seems almost ironic that the political language used to address the minority status of the Roma has given rise to further misunderstanding and marginalisation of groups like the Roma. Further enquiry needs to address this paradigm shift in a way that "dissolves the classical rigidity of the Self/Other and more aptly reflects the specific conditions of globalisation in the twenty-first century" (de Burgh-Woodman 2014: 290). The use of umbrella language in the discourse of the Roma underpins the lack of focused enquiry into the various sub-groups commonly held under this term, and their specific and peculiar identities.

McGarry (2014: 758) cautions that "academics should be careful not to represent Roma as a coherent bloc" and that "Roma, like "the majority" is not a monolithic unit that thinks, acts and feels the same way" Zegarac's (2008: 51) "epidemiological" perspective on culture suggests "it is cultural regularity, rather than cultural diversity, that 
should be surprising", which leads to questions as to why so much of the literature concerning the Roma presents them as a similar and amorphous group, with scant consideration of the country from which they originate or where they reside, or any other possible factors in the formation of their identity, such as the influences of age, gender, education or media. As Engebrigtsen (2011: 124) notes, it is "urgent" to take into consideration the variety between different Roma populations, and to pay attention to the ways in which they are a part of the majority society in which they live. It is one of the aims of this study to give close attention to the attitudes of Slovak-Roma schoolchildren in Britain and to create a space beyond the self/other dichotomy. Poststructuralist theory rejects notions of fixed or "essential" identity, preferring to look at "hybridity" and "third places" and "choice" which according to Block (2006: 37) "work far better... when it comes to making sense of the cases of individuals who have moved between and among qualitatively different sociocultural contexts." The departure from the view of identity as something fixed is outlined by McGarry (2014: 758) as a "process, a performance"; Zhu $(2014 ; 209)$ refers to the emergence of interculturality, rejecting the view of identity as something an individual "either has or does not have". For both McGarry and Zhu identities are not taken a priori and the latter emphasises the role of language practices in their negotiation.

Much existing research into the Roma has been focused on dismantling the self/other dichotomy through examination of European education policy (see Miskovic 2009; Garaz 2014; Rostas \& Kostka 2014; Nistor et al. 2014). Much of this emphasises their marginalisation and exclusion, concluding that many European education systems by design are incompatible with Roma students' lifestyles and culture. For Rostas and Kost$\mathrm{ka}(2014)$ this is evidence of the reproduction of social inequalities which justifies the lack of educational achievement of Roma schoolchildren as evidence of their inability to adapt, rather than as institutional discrimination. This is discussed further by Schneeweis (2012) in a study of press discourses of the integration of the European Roma in which attention is drawn to the blurred line between integration and assimilation, concluding that there can be no discussion of what integration should be without those "typically excluded" (p. 685). This highlights the need for further research in which these hitherto "excluded" voices can be heard. Pnevmatikos et al. (2010) have gone some way to addressing this in a study examining the emergence of ethnic identity in childhood in Roma schoolchildren living in Greece, making some interesting discoveries regarding the interplay between schooling and the participants' attitudes to language. Significantly, it was found that as the children grew older and enrolled in school, their view of the Romani language as a stable and constant aspect of their identity diminished, and by eleven years old, no participant reported feeling that the loss of the Romani language would have a detrimental effect on their identity.

Identity negotiations are based on an increasingly complex set of cultural interactions. Movement of individuals both globally and nationally has led to the emergence of interculturality, however grand narratives of identity do still exist. This is evident in the case of ethnic Roma identity; the majority of literature takes the participants as objects rather than subjects of research and there is a clear propensity to group them 
alongside other travelling communities. This particular grand narrative may need to be dismantled and its constituents re-examined, taking into account other aspects of identity beyond ethnicity, such as nationality, age and language practices.

\section{Research Questions:}

- How do Slovak-Roma schoolchildren in a Medway academy (Kent, UK) negotiate their identities?

- What are their attitudes towards learning English?

- What potential areas of conflict do they encounter?

\section{RESEARCH METHODOLOGY}

\subsection{Participants}

Participants were selected using purposive sampling (Newby 2010) on the basis that they were able to give a particular insight into the research context. A list of potential participants was created; the criteria for selection was firstly self-identification as Slovak Roma, and in the age range of 13-16 years, but initially beyond that there were no stipulations for inclusion or exclusion based on academic achievement in order to harvest a spectrum of views. Ultimately four participants were identified as fulfilling the research criteria: two males and two females. Each participant self-identifies as ethnically Roma and each is resident in one of the three key wards in Medway identified and described in the following section.

Michal $^{1}$ is a fourteen year-old male. He was born in Slovakia but has lived in Medway for the past eight years. He has previously spent time in Belgium. He has returned to Slovakia on a number of occasions. He has a large extended family resident in the UK. He has spent some time in the care of the local authority and is now a looked after child in his grandparents' home. His L1 is Slovakian and he also speaks Romani, although he has degrees of proficiency in a further two languages. Educationally he is four National Curriculum sub-levels below the target for his age group in English.

Ondrej is a fourteen year-old male. His family migrated to England from Slovakia when he was six years old. This migration was for both economic reasons, and because several other family members were already resident in the UK. He was bilingual in Romani and Slovakian before acquiring English as an additional language. He has been in the UK education system consistently since his arrival. In terms of educational progress, he is two National Curriculum sub-levels above the target for his age group in English. He has a large number of both close and extended family members living in Medway.

Sona is a thirteen year-old female. Her family migrated from Slovakia to the UK when she was nine years old for economic purposes. Although now resident in Medway, her family also spent at least a year in another area of the UK. Her L1 is Romani which was the sole language she spoke until beginning school aged four/five in Slovakia, at which time she began to learn Slovakian. She also has degrees of proficiency in three other languages. When she arrived in the UK aged nine she knew very little English. Sona has three brothers close in age to her. In terms of educational progression, she is two National Curriculum sub-levels above the target for her age group in English.

\footnotetext{
1 All names are aliases to protect the participants' anonymity.
} 
Jolana is a fourteen year-old female whose family migrated from Slovakia to the UK when she was seven years old for economic purposes. Her L1 is Romani, but she is also fluent in Slovakian. When arriving in the UK she knew only "some words" in English. She has been in the UK education system consistently since her arrival. She has two older sisters who no longer live in the family home and one younger brother. Educationally she is five National Curriculum sub-levels below the target for her age group in English.

\subsection{Context of the study}

In 2015 the Unitary Authority of Medway, in Kent, found itself at the confluence of a number of significant socio-political, educational and economic events. Nationally, Medway falls into the bottom $20 \%$ of districts for skills and qualifications, long term unemployment and mortality. The Medway census of 2011 reports an increase in the Black and Minority Ethnic population since 2001, with the proportion now standing at $10.4 \%$ against the majority $85.5 \%$ White British population. There has been a $77.6 \%$ increase in Medway's population of those born outside the UK, with the majority of this number self-reporting as being from Continental Europe, Africa, Asia and the Middle East. The proportion of the population born in Europe increased from 1.6\% to 3.7\%, by far the greatest increase of any other category. In $2.9 \%$ of households, nobody has English as a first language. Finally, $1.2 \%$ of the population report that they either cannot speak English, or cannot speak English well. Of this final group, half are to be found living in just three of Medway's wards, all adjacent to one another.

There is great diversity within the Medway school community which comprises a range of ethnic identities and a multitude of languages are spoken, reflecting the demographic of the area in which it is situated. A significant proportion of students selfidentify as "Slovak-Roma". This particular group holds minority status and there is relatively little ethnographic research in which members of this group are audible. Existing research into attitudes towards those identifying as "Roma" in a general sense often emphasises marginalisation and restricted access to opportunities (Miskovic 2009). Hancock (2002) describes their persecution as unparalleled, whilst Engebrigtsen (2011) describes the perpetual re-emergence of historic pejorative attitudes.

\subsection{Research Design}

The research design received ethical clearance from the research institution and permission from the head of the secondary school. Participants' parents gave their permission. The school community liaison officer acted as the intermediary as most of the parents did not speak any English, and some did not read or write in any language. The school community liaison officer explained the consent form to them verbally and then they signed. The first author explained to the participants at the start of each interview what the interview would be about, that their anonymity was guaranteed and added that they could cease participation at any point. The participants also signed a consent form.

The data was collected through four semi structured individual interviews lasting 16, 17, 19 and 24 minutes, which were digitally recorded and transcribed. The interview questions (see Appendix) were designed to explore the research questions by encour- 
aging the participants to reflect on them. When considering the types of questions appropriate to the aim, Patton's (1990) classifications of qualitative research interview questions were considered to frame both researcher perspective and responses needed. Background/demographic questions were necessary particularly in making sense of the data during analysis, but also allowed the participant to self-reflect on their own cultural identity. Secondly, experience/behaviour questions were used, both to reflect on what had been done in the past and what might be done in the future. Finally, opinions/values questions were employed to elicit participants' attitudes and feelings. This research is as much about finding out how the participants felt about the information they were giving as about the actual information itself (Holliday 2007: 4).

Following the model used by Valkanova (2009) and Dewaele and MacIntyre (2014) the main themes discussed here were identified through close study and comparison of the participants' responses during the interview process. The aim of the study was to "give voice" to the participants and their experiences, however from an interpretivist perspective, it is important that the researcher attempts to "see the social world from the perspective of those he or she researches" and uses dialogue to try to "discern the perceptions of others and interpret their meaning and purposes' (Counsell 2009: 263), rather than to impose our own preconceived notions on the evidence. However, through a careful process of close reading and coding, at least five themes emerged clearly.

\section{ANALYSIS}

\section{Theme 1: Perception of Identity by Others}

There were close similarities in participants' recollections of the attitudes of "English" people towards them. Ondrej reports comments such as "we get on their nerves, because we're like taking their jobs, making problems, stuff like that." He also reports comments such as "“Why are we here?" and "Go back to your own country."” Similarly, Jolana remembers being asked "Why did you come to England?" Ondrej complains that pejorative attitudes are evidenced in the comments of some English people, but these are not necessarily specifically directed at his being Roma, but just having a generalised status of immigrant, in which his nationality is conflated with many others. Sona reports that "English people used to call us 'Kosies' and all that", a reference to "Kosovans", a pejorative term for immigrants of a particular appearance. Similarly, Ondrej expands on the ways in which they are perceived:

"Oh, yes. Like some people, like not from Slovakia, but like from different countries, like Romanian, yes, Albanian and stuff like that. They look like us, so I don't know why it is, they look like us but they're just making problems, they're like stealing and stuff like that. They don't want to learn, stuff like that, and I just don't want to be seen as that'.

Interestingly this reveals an awareness in the participant of the ability to negotiate the way in which his identity is perceived and the possibility of a degree of agency in this process. A similar attitude and awareness is found in Sona who reports that upon arriving in England "it was so hard to really change myself", again demonstrating an awareness not just of agency but also alluding to the significance of the influence of a different culture and language on oneself. 
Notably, when explaining negative perceptions, both Ondrej and Sona were anxious to qualify their statements. Ondrej stated: "It's not everybody, it's just like some people", whilst Sona declared: "I'm not trying to be racist or mean." There is a degree of irony here in that both participants are demonstrating great sensitivity in their attribution of others' attitudes, despite this being in response to questions regarding the generalisation of their perceived identity.

\section{Theme 2: Adaptability}

A number of the participants' responses demonstrated the challenges that they had faced in negotiating a cross cultural identity, particularly in terms of the role language learning played in the process of enculturation. Adaptability is evident when Sona describes whether she found moving between cultures difficult: "I used to be, but I'm not anymore, because I'm used to it'. For these participants, language accommodation is reported as "normal", as Jolana remarks, "If I have like Slovakian friends or Czech friends, then I speak to them like that". Michal reports as speaking four languages, and Sona reports as speaking six. Sona reports that "When we was living in Slovakia, we had to speak Slovakian" and that migration to England meant "we had to speak English, we had to do spellings". The repetition of the modal "had to" conveys a sense of obligation felt by the participant. This theme of responsibility is continued by both Michal who states he speaks English "so people understand" and by Jolana who states that in interactions with English people "I have to speak to them in English" because otherwise "they won't understand". What is interesting is the evidence of the participants' degree of personal responsibility for communicative accommodation. Jolana does not state that she cannot make herself understood, but rather the responsibility is with her to converge with her environment to ensure those around her are not inconvenienced. She reports that she does not mind doing this, revealing a pragmatic and adaptable attitude towards the learning of English. It is worth noting additionally that Jolana's expression differs from that of Michal. For Michal the purpose of code switching is so "people" understand. Jolana, in contrast uses "they" and "them", potentially constructing an in-group/out-group dichotomy. The value of speaking the English language in adapting to the culture is further reflected on by Ondrej:

“...English people, they always see I speak English, the English, but this is English country, like this is England, this is English school, stuff like that. So it will be better I will speak... if I spoke English".

This again reveals a pragmatic attitude towards the acquisition of English and an awareness of the role language plays in enculturation. There is an interesting change of tense from "I will speak" to "if I spoke" in which the self-correction to the conditional tense actually evidences the participant's proficiency in the language. The motivation for this may be found in Ondrej's recognition of the potential for positive feedback through language competency when he states that "Sometimes we speak English outside, so like the English people thought, yes, they go like, yes." The benefits of competency in the English language to the participants are further explored in the next section. 


\section{Theme 3: Aspirations}

There was evidence of strong aspirations in some participant responses. There was a clear link made between the learning of English and the ability to make progress. The strongest of these attitudes were expressed by Sona, who describes a transitional period:

"When we was in Year 7 we used to be so talking and swearing. We used to do bad stuff, but since we got into Year 8, we was like, 'Oh my God, we have to change our behaviour. What did we do?"”

She describes the role English speaking amongst her social group played in this transition:

"C answered her in English, and I think I started English in questions with him. So then I was like, 'Why are they speaking English?'. So then I was like, 'Why do you two talk English?'. She said, 'Because you have to, because this is England'. So then, me, I started talking English with C, then AM started talking to me, and really, I don't know, I just love this school. This school pushed me up so much. I didn't used to be like that".

Perhaps this is not surprising when we consider that Sona is currently two National Curriculum sub levels above the target for her age group in English. The aspirations of Sona have extended to those around her; having felt that "English girls pushed me" she states an ambition to do the same for her family and "move my little sister... I can push her up with English." Reporting that her mother does not yet speak English, despite having lived in England for five years, Sona states a desire to "try to help her out" and justifies to her the use of English at home saying: "That's why we talk English with you so we can at least a little bit push you up". Noticeably the language used equates proficiency in English with ascension, however the verb 'push' also connotes compulsion or demand, an attitude which is reported by Sona in conversations with other members of her ethnic group demonstrating the conflicting influences on her performance.

"Every time I say something in English, she says, 'Oh my God, you're not English, so don't speak English', but I ignore her. So, I even like make her, not upset, but make her crazy so I can push her into it, as well. So I do that as well, but sometimes it works, sometimes it doesn't. Sometimes she hits me, so I don't speak English."

The link between aspiration and group identification is also discussed by Ondrej, who states that his ethnically Roma mother

“doesn't allow me to have Roma friends... She says, if I've been with them, I wouldn't learn anything, I will just make problems and stuff like that. She wants for me to study for going to college."

This seems to represent an attitude towards mobility which is augmented by Ondrej's reflections on his own cultural identity; he reports as being "Slovakian" primarily during the recorded part of the interview, and answers "Not really," when asked whether he has ever felt that he cannot say he is Roma. However, at the conclusion of the interview, after the recording device had been switched off, Ondrej embarked on a clarification of some of his answers stating that during Year 8 he was rejected by many of his Roma peers for "not making trouble enough". He draws a clear link between his acquisition of English and his aspirations: "It will give me advantages in the future, 
like because then I could get somewhere, get a job and stuff like that" and feels that there is potential for his children, "Like, better future for them". To this end he reports motivation to continue to refine his English language skills, "We want to improve our English and our accents" and to continue to "acts like English people".

Aspirations were not as evident in all participants. For Jolana English is "good because it makes you like learn like more things" but qualifies this with the attitude that "you have to learn it... because you won't understand anything." This pragmatism is in contrast to the more specific benefits, similar to those of Ondrej, identified by Sona which she clearly links to her future plans: "I want to stay [in England], I want my kids to be here as well." Her reflections on her own experience form the basis of her future aspirations:

"My family chose to come here, they [her future children] will have to do the same thing as us. They'll want to go, so if they live here and then straight away pushed us up in English, so they know everything. So they wasn't like... I don't want my kids to live the same thing, life as I did."

Despite clearly recognising the difficulties of her situation, Sona maintains aspirations for her future based on her language competence suggesting she would like to work in the travel industry as she could fulfill a role that requires someone who "talks different languages." This is unusual as she clarifies that usually "girls like sixteen/seventeen get married, children, and that's why I said, I just don't want the same life as they do." Again, evident here is a lack of homogeneity.

\section{Theme 4: Self-Perceptions of Identity}

In contrast to the view of the Roma as a homogenous group, for whom their ethnic identity is an over-arching feature, the participants' reflections on their own identities revealed, even in such a small sample, a distinct degree of variation. Jolana repeatedly refers to "our country", as does Ondrej, revealing a clear identification with a Slovakian national identity. Ondrej states that he would identify himself primarily as "Slovakian", and then "Roma", however Jolana explains that "I'm Roma because it's just how I always was since I was born." Yet Slovakian national identity is clearly an important dimension for both participants. In contrast, Michal's responses suggest ambiguity, demonstrating no particular allegiance to any specific location and stating he would not mind living in "any other town, any." Sona does not use possessive pronouns to refer to Slovakia, but does state that, "because I'm from Slovakia, I don't want to forget about my language" and that "sometimes I do feel like Slovakian, and sometimes I feel like English... I feel in the middle." What appears clear here, is that despite her assertion that "I don't want to go back to Slovakia" it still holds a significant influence on her self-perception of identity. Noticeably, during the interview Sona only ever referred to negotiations between a Slovakian and English identity, calling into question just how significant her ethnic identity has become for her.

It is noticeable with a number of the participants that national identity appears to be considered as more significant than ethnic identity. For Ondrej, his Roma ethnicity is something he has difficulty reconciling. After the recorded interview, he reported 
conflict between the way he is perceived in England, stating that in Slovakia he only had Slovakian, not Roma, friends and that "My family don't even look like Roma". However, he currently feels "poor" and that people just think we "sing and dance" perhaps referencing the stereotypical myth of the 'gypsy' as the other. A further concern was the way in which he felt perceived to be like other traditionally travelling communities, such as English Travellers, groups with which he did not self-identify at all. Yet for Ondrej being Roma is clearly an important facet of his identity. He explained the role of religion in Roma culture, emphasising the strength of belief that they all have a place in Heaven as being based on the fact they have no homeland and exhibiting a great deal of pride in his culture. However, he is very aware of the connotations attached to the Roma ethnicity:

"Like, even if it's our country, like we live in Slovakia, all the generations, but like if they saw Roma people like wanted to get a job, they wouldn't like take us, because they... I don't know why it is, they're just racist. Like not all people, just some ones."

There is a distinct self-awareness in the ways in which they are perceived through many of the participants' comments. Ondrej goes on to question why "they take all the people and think that we are all same but we're not, because like everybody was brought up differently." Jolana continues in this vein:

“In our country [Slovakia], like many others, we don't live like all together, because they live all apart. So they live... Some Roma are like dirty, but some aren't. Like it depends on what family they have and like that. But like, we are different, but some of them, say like $\mathrm{C}, \mathrm{S}$, me and $\mathrm{C}$, and $\mathrm{N}$, like we are all different and my cousin, and that, but some that come with us, they are different as well, because they are like... Some are dirty, some are living in a dirty house or something."

Jolana here refers to "we" and "they" pointing out that for her, there are clear differences within the Roma community. She also refers to "our country", again reinforcing the importance of Slovakian nationality on her identity. In other parts of the interview she refers frequently to Romani as "our language" and "my language". For her, language is a site of negotiation. When asked to indicate a preference for English or Roma culture she "would pick Roma because it's my language", which is a clear indication of this participant's personal link between her language and her culture. Other participants also offer views regarding language and their identity. Ondrej reports that Romani is rarely spoken in his family, and speaking Romani "is like nothing" in terms of its importance. Describing language habits of the Roma in Slovakia, he states: "It's like in my country, they didn't actually speak Romani, they spoke Slovakian all the time." Michal describes only speaking Roma as a last resort:

"If I told a story, I would talk Slovakian, and if I don't do like the word, for example, I couldn't do it well... I would say it in English, and if I really don't understand it in English, I will say it in Romani."

For Jolana, despite Romani being her L1, and only having learnt Slovakian at age four/five, she reports her main language now as being English,

"because things like in the world... English is main language so you can learn. Because when you go to job and your spellings and writing and everything is right, so you're English". 


\section{Theme 5: Conflict}

There was evidence across the participants' responses of a particular understanding of what they saw as necessary to adapt to the norms of a new culture and environment. Sona repeats the idea of sticking to 'the rules'. In response to a question asking her about how she deals with negative attitudes expressed towards her she felt that "I just need to carry on with the rules." And when asked about the difficulties in being both Roma and English, she asserted that "I have to carry on the rules and just get on with it really." The role of English language learning is highlighted again when she reports having been told "Speak English, you're in an English country, so don't break the rules." However pragmatic Sona's approach might appear to be, the difficulties of converging to language expectations are expressed by Jolana who states:

"They don't even know how to feel, like if you have to speak always just English, not your language, they think it's like very easy to just speak to your friends like in English if they are like from your culture and they are Roma. But they have it easy because they have English..."

This demonstrates that Jolana feels pressure to reject her own L1 in order to adapt, and evidences a lack of accommodation from L1 English speakers who have no understanding, in her view, of the difficulties in expressing oneself in a language which has had to be learned. The role of acquiring English in order to adapt is also emphasised by Ondrej, who states that the most important thing one needs to do to be English is "Like speak English. All the time... even at home". However, there is conflict reported in language as a site for identity; "I get confused; speak that language, speak language, speak that language".

\section{DISCUSSION}

\subsection{Perceptions of Identity by Others}

At least two of the participants reported negative perceptions based on their Roma ethnicity. An oft-repeated explanation for the position of the Roma is an anachronous attitude which privileges Roma ethnicity above all else and represents it as unrealistically homogenous (Levinson 2014; Engebrigtsen 2011). This attitude, although perhaps born from an ideological aspiration to respect and preserve a minority ethnicity (see Nistor et al. 2014), paradoxically could serve to reinforce an outdated sense of enclosed and immutable otherness. Perhaps Roma ethnicity is being singled out as the single determinant factor of identity, 'manufactured by uncompromising binarization' (Levinson 2014: 16), and there is a failure to perceive individuals of Roma ethnicity as being influenced by globalising forces which are so comprehensively discussed in relation to contemporary identity negotiations (see Bhatia \& Ram 2009; Omoniyi 2010; O’Neill 2013). The findings suggest that perceptions of the participants still evidence a degree of essentialism and, in juxtaposition to Antaki and Widdecombe's (1998) interculturality perspective, that the participants' ethnic identity is ascribed permanent salience externally.

The evidence of 'othering' in the ascription of the participants' identities corresponds with McGarry and Drake's (2013) identification of them as the 'ethnic other'. 
These attitudes were reported as occurring primarily in Slovakia, but the existence of the 2014 Ofsted Report into 'Overcoming Barriers in the Roma Community' and the 'East European Roma Culture Awareness Guide' (Felja \& Smolinska-Poffley 2014) published specifically to aid the Metropolitan Police, suggests that in the UK Roma ethnicity is still given a great deal of special attention. Ironically, the participants' negative perceptions in Slovakia are based entirely on their Roma ethnicity (Nistor et al. 2014) but there now appears to be a further complication of their identity; they attract negative connotations and rigid ascriptions of their ethnicity but their appearance is additionally taken as an index of 'East European Migrant'. Tracy's (2002) categorisation of national identity as a 'master' identity suggests we should not be surprised that that in the context of global movement there is a tendency to label individuals based on their geographic origins. Although much existing literature on the Roma emphasises their ethnicity as a site for oppression and persecution (Hancock 2002), here they find their identities demarcated by a cruder boundary (Edwards 2009) apparently drawn between 'native' British and everyone else. Their ability to adapt to this and their own self perceptions are discussed in subsequent sections.

\subsection{Adaptability}

For all participants, language was extensively discussed as key site of identity negotiation. All participants report speaking between three and six separate languages. Koven (2001) suggests that speaking a different language can be a way of performing a different version of the self, or in other words the acting of a social role. Dewaele (2010) posits that the connotations of that language are transferred to the speaker's selfperception albeit in this case temporarily, perhaps a reflection of what Blommaert (2007) considers to be a deliberate act to position the self within the socio-cultural order. For Jolana the learning of English appears born of necessity. This appears to be a quite pragmatic and accommodating attitude but is perhaps evidence of only a superficial practical shift rather than having a significant influence on core identity. Furthermore there is a clear polarisation of in-group and out-group in her responses, a perspective not found in all participants. In this case, language accommodation could be considered a mechanism through which a minority culture protects itself (Levinson 2014); the acquisition of enough language to placate the need to engage with capital, but only in terms of social survival. For Jolana speaking many languages is described as 'normal' which suggests there may be a stable sense of the self, independent of the language spoken. The findings of Pnevmatikos et al. (2010) would seem to support this, in that the constancy of the language spoken was not reported as a key indicator of the stability of identity. At first this may be seen to contradict Zhu's view that 'language practices and identity are mutually dependent and interconnected' (2014: 218) but of course we must remember that the choice not to speak a language is as deliberate an act as the choice to speak it. A 'one language; one culture' model seems erroneous here; as Edwards (2009; 205) suggests, we should be cautious of equating one particular language with a feeling of 'groupness'; it is possible that a strong sense of group identity can prevail despite adapting to the use of alternative communicative codes. 
The ability to survive, and maintain their group identity, is what Valkanova credits as one of the greatest achievements of the Roma (Valkanova, personal communication, 4/3/2015). She asserts that as a nationless ethnicity, it has been their ability to adapt without changing that has seen them prevail as a group for so long. However, underlining the imprudence of viewing the Roma as homogenous, as Levinson and Hooley (2013) warn, for Sona language practices seem to exert a stronger effect on her personal identity. She describes learning English at school as being, "so hard to really change myself", alluding to the significance impact a different culture and language has had on her personal sense of identity, echoing Blommaert's perspective that it is not simply learning the words of a different language, but learning how to 'be' (2007). The question arises here as to how far the participants are being, and how far they are becoming. O'Neill (2013) suggests that individuals become 'actors in their own narratives' and 'present preferred selves who strategically negotiate interactions' (pp. 386-7). This leads us to question whether the adaptability evidenced by the participants is always a sincere performance or an accommodation which actually serves to protect the ingroup identity.

\subsection{Aspirations}

Two of the participants, Ondrej and Sona, demonstrate extremely positive attitudes towards the learning of English and the potential benefits this could confer upon them, but are also candid about the difficulties they have experienced when learning a new language and express a desire to create a "better future" for their own children. It is not surprising therefore to find that both these participants are two NC sub-levels above the English target for their age-group, and at least six sub-levels above the other two participants. This reflects Blommaert's (2005) perspective that one's life chances are dictated by one's ability to manage movement across languages. Sona's reflections on her progression in English consistently equate proficiency with ascension, repeating the phrase 'push up' in relation to continued mastery of the language, demonstrating an attitude that acquisition of the English language will increase her range of opportunities and raise her status; but this 'push' also connotes effort and seems to represent her own intrinsic motivation to provide what she sees as valuable cultural capital for her future children. Whilst inheritance from parent to child is often taken for granted, there is an interesting change in perspective in that both participants also describe attempts to improve their parents' knowledge of the English language. Again the verb 'push' is repeated, suggesting the potential for the English language to raise her mother's status. It also connotes the idea of struggle, and it may be that there is resistance to change, perhaps what we have previously identified as the strength of the in-group boundaries. It appears that these participants' attitudes converge with the results of Zhu's (2010) study in which it was found that the younger generation have the capacity to autonomously construct new cultural and social identities through interactions, and that through language socialisation they have the capacity to actively bring about changes within their own communities. The findings of this study question whether generational differences are beginning to override ethnic differences. 
The potential significance that the language being acquired is English should be recognised. Crystal (1997) identifies it as the globally dominant language, and it is seen to connote status, modernity and to facilitate social advancement. For Sona, despite Romani being her L1, and only having learnt Slovakian at age four/five, she reports that English is her main language now. Previously we have questioned whether the acquisition of language is an accommodation which actually serves to protect the in-group boundaries, yet here participants seem to equate speaking English with being English, with the concomitant benefits of this (Giles \& Billings 2004). The role of English as a language of prestige, modernity and global utility, may boost participants' motivation to acquire it when compared to other languages. However, if the language is acquired as a form of symbolic capital, it may not outweigh the value of the language spoken within the family if, as in this study, it is not English, as language continues to be seen as an important symbol of group identity and social solidarity (Dorian 2010).

Dewaele and Nakano (2012) remind us that the process of learning a new language can provide the motivation to achieve hitherto unimagined goals and this could be an explanation for some of the participants' rejection of in-group cultural expectations: "I just don't want the same life as they do." Pnevmatikos et al. (2010) identified early betrothal and marriage of Roma children as a central ring of their ethnic identity. In Medway, the rate of pregnancy for 15-17 year old girls has been reported as one in twenty. One participant clearly rejects the option of early marriage and this could be seen as a re-positioning of her identity in that she is not just comparing herself within her ethnic group, but within her generation and her wider peer group too. Identity comparisons outside of ethnicity are also facilitated through inclusion in mainstream education. Previous studies have emphasised the educational segregation of Roma communities and attribute to this a lack of aspirations and educational success. In this study, the participants are all enrolled in mainstream education, and there is clear evidence of an agenda in the UK of ensuring inclusion, such as the Ofsted report (2014), Overcoming Barriers, which highlights that pupils acquire language more readily when placed with first-language English peers, rather than being taught in segregated units. As one participant notes, "school pushed me". For two participants, exceeding their target English levels appears to be evidence of the success of this education policy and enables them to create aspirations. Of the remaining two participants, who are well below their targets, it must be noted that one has spent a great deal of time in the care of the local authority and this experience is likely to produce a confounding variable.

\subsection{Self-Perceptions of Identity}

The participants in this study occupy difficult territory. Despite strong self-identification as being of Roma ethnicity, all participants additionally identified strongly as 'Slovakian'. This reflects findings that "many Roma in Slovakia consider themselves to be Slovaks or Hungarians and identification with the majority is more significant than their Roma identity" (Covrig 2004: 94). Sona only ever refers to her identity as being either Slovakian or English, and Ondrej emphasises his Slovakian identity over his ethnic identity adding that his family doesn't even look like Roma. This brings another com- 
plicating dimension to the negotiation of their identities, especially that Roma identity can reduce access to opportunities in Slovakia. National identity may be fundamental and inclusive (Smith, 1999) and yet, ironically, these participants report exclusion from their national identity based on their ethnicity. This may reflect the continuing binarization of the Roma as the 'other', and the weight attributed to the strength of their in-group culture (McGarry 2010; Levinson 2014). This reminds us of Engebrigtsen's (2011: 124) advice that it is 'urgent' to take into consideration that the Roma are part of the majority populations in which they live; certainly for these participants their national identity is a hugely important dimension of their identity and yet one, as we see in policy documents such as the Ofsted Report (2014), which is totally overlooked. The results of this study, although small scale, demonstrate that in the case of the Roma, national identity must be taken into consideration.

\subsection{Conflict}

The perceptions and expectations of others are at the core of much of the conflict felt by the participants. Participants report a lack of accommodation from English L1 speakers in understanding the difficulties when communicating in English, more specifically the feelings of inability to be natural, and having to create an artificial performance, something that Pavlenko describes as 'anguish' (2006: 29). Perhaps here we can highlight the possibility of a revision of perceptions; rather than seeing the Roma as refusing to assimilate, a perspective reported by Miskovic 2009; Garaz 2014; Rostas and Kostka 2014; and Nistor et al. 2014, it may be useful to consider that their difficulties are similar to other multilinguals negotiating between languages and contexts.

However, it is not just feelings of discomfort when using English which are a source of conflict; Sona reports that her choice to speak English the majority of the time causes conflict within her ethnic community, "Sometimes she hits me, so I don't speak English." Despite the view that convergence to the dominant language code can convey a great deal of symbolic capital upon the speaker (Giles \& Billings 2004), in this case, convergence with the dominant language form is not necessarily conveying any sort of prestige but has consequent negative peer evaluation (see Edwards, 2010; Marlow $\&$ Giles 2010). This draws attention to the potential difficulties that could be experienced by an individual who finds themselves caught in a web of cultural expectations which may be conflicting; as Levinson suggests, the 'darker outcomes' (2014: 2). Here the use of English moves beyond its denotative function and is connoting an alternative identity; Michal reports being told by a member of her community, "You're not English, so don't speak English". This example of language criticism shows that for the participants in this study, the negotiation of their identity is a complex, shifting set of circumstances in which they must negotiate between criticism from the dominant culture for not speaking English but perhaps even stronger criticism from their own ethnic in-group for speaking it. Because of the small sample size and that unique geographical context it is impossible to make generalisations from this research. However, the analysis of the qualitative data allows us to question the prior conceptualisations of Roma ethnicity which have hitherto, as Pavlenko and Blackledge (2004:19) say, 'reigned uncontested'. 


\section{CONCLUSION}

Intercultural studies emphasise the continual negotiation of cultural membership, ascription by others and self-orientation. The results of this study suggest that there is still a strong element of ascription by others in terms of the nature of participants' ethnicity and its relationship to their identity. However, what is not considered in detail are their other cultural memberships. It is clear that the participants strongly identify with nation and therefore future research may wish to investigate this further, as opposed to continuing to align ethnic Roma with other travelling communities.

There is a paradox in that participants in this study cannot be viewed as a coherent bloc; they reported individual aspirations, identifications and attitudes. And yet, despite the differences described and the lack of a state, the Roma ethnicity has survived for a considerable time. It is necessary to consider how far the researcher may have been told what she wanted to hear, or how superficial the adaptations of the participants might be. The question remains as to the strength of endogamy and in-group identity, which as this study has shown may exist independent of language shifts, and the juxtaposition with the possibilities that the aspirations of the younger members of the community report. In a post-modern world there are greater opportunities for more complex constructions of identity. Furthermore, the participants in this study are all enrolled in mainstream education and of them, two are achieving above national targets which can also be seen as a site of alternative opportunities. There may be merit in additional cross-generational investigations of how far increased choice and opportunity might weigh against traditional ethnic constructions of identity.

Finally, more small-scale studies such as this will allow for greater opportunity for self-representation. As one participant said in her interview, on leaving the room, "I want people to know what I can do, not what I can't do, and no one knows what I can do".

(C) Laura Hryniewicz, Jean-Marc Dewaele, 2017

\section{APPENDIX}

The questions below were not asked in any particular order, but were used as prompts during discussion with the participants to encourage reflection on their responses.

Context Questions:

- Family/extended family resident in the UK?

- Number of Years in UK?

- Just in Medway?

- Previous countries?

- Parents speak English?

- Which language at home?

Experience/Behaviour and Opinions/Values Questions:

1) What do you think you need to do to be English?

2) What do you need to do to be Roma?

3) Who do you feel similar to? 
4) Who do you feel different from?

5) Who do you not want to be like?

6) Does everyone see you in the same way?

7) Do you ever feel you have problems with who you are?

8) How far is speaking Romani an important part of your identity?

9) Why is speaking English important to you?

10) Who do you speak Romani to?

11) Who do you speak English to?

12) Do you speak any other languages?

13) Which is the most natural language for you?

14) Are you Slovakian?

15) Are you seen as Slovakian?

16) Would you ever tell someone you were something that you're not?

\section{REFERENCES}

Antaki, C. \& Widdicombe, S. (eds.) (1998) Identities in Talk. London: Sage.

Bhatia, S. \& Ram, A. (2009) Theorising identity in transnational and diaspora cultures: a critical approach to acculturation. International Journal of Intercultural Relations, 33, 140-149.

Block, D. (2006) Identity in applied linguistics. In T. Omoniyi \& G. White (eds.) The sociolinguistics of identity. London: Continuum, 34-49.

Blommaert, J. (2005). Discourse. A critical introduction. Cambridge: Cambridge University Press.

Blommaert, J. (2007) Sociolinguistics and discourse analysis: Orders of indexicality and polycentricity. Journal of Multicultural Discourses, 2, 115-130.

Bugarski, R. (2012) Language, identity and borders in the former Serbo-Croatian area. Journal of Multilingual and Multicultural Development, 33, 219-235.

Counsell, C. (2009) Interpretivism: Meeting ourselves in research. In E. Wilson (Ed.), School-based Research: A Guide for Education Students. London: Sage, 251-276.

Covrig, A. (2004) Why Roma do not declare their identity — careful decision or unpremeditated refusal. Journal for the Study of Religions and Ideologies, 8, 90-101.

Cresswell, J.W. (2007) Qualitative inquiry and research design: choosing among five approaches. Thousand Oaks. CA: Sage.

Crystal, D. (1997) English as a Global Language. Cambridge: Cambridge University Press.

De Burgh Woodman, H. (2014) Homogenity, "glocalism" or somewhere in between? A literary interpretation of identity in the era of globalisation. European Journal of Marketing, 48, 288-313.

Dewaele, J.-M. (2010) The perception of French by native speakers and advanced L2, L3 and L4 learners. In V. Regan \& N. Chasaide (eds.), Language Practices and Identity Construction in French. Bern: Peter Lang, 133-156.

Dewaele, J.-M. \& Nakano, S. (2012) Multilinguals' perceptions of feeling different when switching languages. Journal of Multilingual and Multicultural Development, 34, 107-120.

Dewaele, J.-M., \& MacIntyre, P. (2014) The two faces of Janus? Anxiety and Enjoyment in the Foreign Language Classroom. Studies in Second Language Learning and Teaching, 4, 237-274.

Dorian, N. (2010) Linguistic and ethnographic fieldwork. In J. Fishman \& O. Garcia (eds.), Handbook of Language and Ethnic Identity. Oxford: Oxford University Press, 24-41. 
Edwards, A. (2010) Learning How to Know Who: professional learning for expansive practice between organisations. In S. Ludvigsen, A. Lund \& R. Saljo (eds.), Learning across Sites. London: Routledge.

Edwards, J. (2009) Language and Identity. Cambridge: Cambridge University Press.

Edwards, J. (2010) Language Diversity in the Classroom. Bristol: Multilingual Matters.

Engebrigtsen, A. (2011) Within or outside? Perceptions of self and other among Rom groups in Romania and Norway. Romani Studies, 21, 123-144.

European Union (2014) Free Movement - EU Nationals. Available at: http://ec.europa.eu/social/ main.jsp?catId=457 (Accessed: 30 December 2014).

Extra, G. (2010) Mapping linguistic diversity in multicultural contexts: demolinguistic perspectives. In J. Fishman \& O. Garcia (eds.), Handbook of Language and Ethnic Identity (pp. 107-122). Oxford: Oxford University Press.

Felja, D. \& Smolinska-Poffley, G. (2014) East European Roma Culture Awareness Guide. The Roma Support Group. (Felja, D. \& Smolinska-Poffley, G. (2014). travellerstimes.org.uk/UserFiles/.../ Roma-Culture-Awareness-Guide-for-Police\%201.pdf.

Feldman, C., Stone, A., \& Renderer, B. (1990) Stage, transfer and academic achievements in dialect speaking Hawaiian adolescents. Child Development, 6, 472-84.

Garaz, S. (2014) Helping the marginalised or supporting the elite? Affirmative action as a tool for increasing access to higher education for ethnic Roma. European Educational Research Journal, 13, 295 (pp. 274-316).

Giles, H., \& Byrne, J. (1982) An intergroup approach to second language acquisition. Journal of Multilingual and Multicultural Development, 3:1, 17-41.

Giles, H., \& Billings, A. (2004) Language attitudes. In A. Davies \& E. Elder (eds.), The Handbook of Applied Linguistics (pp. 187-209). Oxford: Blackwell.

Gumperz, J. (1982) Discourse Strategies. Cambridge: Cambridge University Press.

Hancock, I. (2002) We are the Romani people. Hatfield: Centre des Recherches Tsiganes (Gypsy Research Centre) and University of Hertfordshire Press.

Hall, S. (1992) The Question of Cultural Identity. In S. Hall, D. Held, A. McGrew (eds.), Modernity and Its Futures. 274-316. Cambridge: Polity Press.

Holliday, A., Hyde, M., \& Kullman, J. (2004) Intercultural Communication. London: Routledge.

Holliday, A. (2007) Doing and Writing Qualitative Research. London: Sage.

Huysmans, J. (2006) The Politics of Insecurity: Fear, Migration and Asylum in the EU. London: Routledge.

Koven, M. (2001) Comparing bilinguals' quoted performance of self and others in telling the same experiences in two languages. Language in Society, 30, 513-558.

Koven, M. (2007) Selves in Two Languages. Amsterdam: John Benjamins.

Leung, H., Hendley, M., Compton, R., \& Haley, B. (eds.) (2009) Imagining Globalisation: Languages, Identities and Boundaries. New York: Palgrave Macmillan.

Levinson, M. \& Hooley, H. (2013) Supporting the learning of nomadic communities across transnational contexts: exploring parallels in the education of UK Roma Gypsies and Indigenous Australians. Research Papers in Education, 29, 373-389.

Levinson, M. (2014) 'What's the plan?' 'What plan?' Changing aspirations among Gypsy youngsters, and implications for future cultural identities and group membership. British Journal of Sociology of Education, 36, 1149-1169. 
Marlow, M.L., \& Giles, H. (2010) 'We won’t get ahead speaking like that!' Expressing and managing language criticism in Hawai'i. Journal of Multilingual and Multicultural Development, 31, $237-251$.

Medway Census (2011). Available at http://www.medway.gov.uk/pdf/Census\%20Report\%20Final.pdf (Accessed at 07/01/15).

McGarry, A. (2010). Who speaks for Roma? Political Representation of a Transnational Minority Community. London: Continuum.

McGarry, A. (2014) Roma as a political identity: exploring representations of Roma in Europe. Ethnicities, 14, 756-774.

McGarry, A. \& Agarin, T. (2014) Unpacking the Roma participation puzzle: presence, voice and influence. Journal of Ethnic and Migration Studies, 40, 1972 - 1990.

McGarry, A. \& Drake, H. (2013) The politicization of Roma as an ethnic "other": security discourse in France and the politics of belonging. In U. Korkut, G. Bucken-Knapp, A. McGarry, J. Hinnfors, \& H. Drake (eds.), The discourses and politics of migration in Europe. 73-91. New York: Palgrave Macmillan.

McGuigan, J. (2010) Cultural Analysis. London: Sage.

Miskovic, M. (2009) Roma education in Europe: in support of the discourse of race. Pedagogy, Culture and Society, 17, 201-220.

Murray, C. (2012) A minority within a minority? Social justice for traveler and Roma children in ECEC. European Journal of Education, 47, 569-583.

Newby, P. (2010) Research Methods in Education. London: Routledge.

Nistor, N., Stanciu, D., Vanea, C., Sasu, V.M., \& Dragotâ, M. (2014) Situated learning in young Romanian Roma successful learning biographies. European Educational Research Journal, 13, $311-324$.

Ofsted Annual Report (2014) Available at https://www.gov.uk/government/collections/ofstedannual-report-201314 (Accessed 30.12.14).

Omoniyi, T. (2010) Borders. In J. Fishman \& O. Garcia (eds.) Handbook of Language and Ethnic Identity. Disciplinary and Regional Perspectives. Oxford: Oxford University Press, 123-134.

O'Neill, F. (2013) Making sense of being between languages and cultures: a performance narrative enquiry approach. Language and Intercultural Communication, 13, 386-399.

Panicacci, A. \& Dewaele, J.-M. (2017) “A voice from elsewhere”: Migration, personality and multiple selves in multiple languages. International Journal of Multilingualism. DOI: 10.1080/14790718.2016.1273937.

Patton, M. (1990) Qualitative Evaluation and Research Methods. CA: Sage.

Pavlenko, A. (2006) Bilingual selves. In A. Pavlenko (ed.), Bilingual Minds Emotional Experience, Expression, and Representation. Clevedon: Multilingual Matters, 1-33.

Pavlenko, A., \& Blackledge, A. (2004) Negotiation of Identities in Multilingual Contexts. Clevedon: Multilingual Matters.

Piller, I. (2011) Intercultural Communication: A Critical Introduction. Edinburgh: Edinburgh University Press.

Pnevmatikos, D., Geka, M., \& Divane, M. (2010) The emergence, structure and development of ethnic identity during childhood: the case of Roma identity. International Journal of Psychology, 45, $435-442$. 
Rostas, I., \& Kostka, J. (2014) Structural dimensions of Roma school desegregation policies in central and eastern Europe. European Educational Research Journal, 13, 268-281.

Samers, M. (1998) Immigration, 'ethnic minorities' and 'social exclusion' in the European Union: a critical perspective. Geoforum. 29, 123-144.

Schneeweis, A. (2012) If they really wanted to they would: The press discourse of integration of the European Roma, 1990-2006. International Communication Gazette, 74, 673-689.

Sharma, M. (2011) Language and the negotiation of identity and sense of belonging: a study of literary representations of Indians in England. Language and Intercultural Communication, 11, 351-363.

Smith, A. (1999) Myths and Memories of the Nation. Oxford: Oxford University Press.

Tracy, K. (2002) Everyday Talk: Building and Reflecting Identities. New York and London: Guilford Press.

Valkanova, Y. (2009) Being a rara avis: the educational experiences of Bulgarian children in schools in Great Britain. In J. Eade \& Y. Valkanova (eds.), Accession and Migration: Changing Policy, and communication. In H. Spencer Oatey (ed.), Culturally Speaking. 48 - 70. London: Continuum.

Vesey-Fitzgerald, B. (1973) Gypsies of Britain: An Introduction to Their History. Newton Abbott: David \& Charles.

Zhu, H. (2010) Society and Culture in an Enlarged Europe. 101-131. Farnham (UK): Ashgate.

Zegarac, V. (2008) Culture Language socialisation and interculturality: address terms in intergenerational talk in Chinese diasporic families. Language and Intercultural Communication, 10, $189-205$.

Zhu, H. (2014) Exploring Intercultural Communication. London: Routledge.

\section{Article history:}

Received: 13 January 2017

Revised: 15 February 2017

Accepted: 22 February 2017

\section{For citation:}

Hryniewicz, L. and Dewaele, J.-M. (2017). Exploring the Intercultural Identity of Slovak Roma Schoolchildren in the UK. Russian Journal of Linguistics, 21 (2), 282-304.

\section{Bio Note:}

Laura Hryniewicz, MA in Applied Linguistics from Birkbeck, University of London, Director of Key Stage 5 at an English academy school. Research interests: global influence of the English language, intercultural identity. Contact information: e-mail: laurahryniewicz@hotmail.com

Jean-Marc Dewaele, PhD in French “Applied Linguistics”, professor at Birkbeck, University of London, President of the International Association of Multilingualism, General Editor of the International Journal of Bilingual Education and Bilingualism, member of editorial board of Russian Journal of Linguistics. Research interests: Second Language Acquisition, Applied Linguistics, Foreign Language Learning, Psycholinguistics, Acculturation, Intercultural Communication, Language Teaching, Language Learning, Cross-Cultural Communication, Language Acquisition, English Language, SLA, Language, Teaching English as a Foreign Language, Emotion, Bilingualism, Discourse, Pragmatics, Language Development, Quantitative Research, Foreign Languages. Contact information: e-mail: j.dewaele@bbk.ac.uk 


\title{
ИЗУЧЕНИЕ МЕЖКУЛЬТУРНОЙ ИДЕНТИЧНОСТИ РОМА-СЛОВАЦКИХ ШКОЛЬНИКОВ В ВЕЛИКОБРИТАНИИ
}

\author{
Лаура Хриниевич, Жан-Марк Деваеле \\ Лондонский университет \\ 26 Russell Square, WC1B 5DQ Лондон, Великобритания
}

\begin{abstract}
Среди большого количества трудов, посвященных народности рома, сравнительно мало тех, в которых можно «услышать» голоса ее представителей. В данном исследовании, проведенном в русле межкультурной коммуникации, анализируется восприятие идентичности четырех рома-словацких школьников в возрасте 13-14 лет, живущих в Великобритании и обучающихся в государственной школе. Интервью с ними были посвящены роли языка в конструировании их идентичности, восприятии «чужих» и природе потенциальных конфликтов. В результате качественного анализа было выделено пять ведущих тем: восприятие идентичности «чужими», адаптивность, устремления, самовосприятие и конфликт. Исследование показало, что идентичности участников более динамичны, нежели считалось при традиционном бинарном подходе (McGarry \& Agarin 2014). Существует устойчивая тенденция приписывать представителям рома порицаемые черты, основанные на их этнической принадлежности. В центре самовосприятия рома - их этническая и национальная идентичность.
\end{abstract}

Ключевые слова: конструирование идентичности, этническая и национальная идентичность, межкультурная коммуникачия, рома-словаикие школьники в Великобритании, качественный анализ

\section{История статьи:}

Дата поступления в редакцию: 13 января 2017

Дата принятия к печати: 22 февраля 2017

\section{Для цитирования:}

Hryniewicz L. and Dewaele J.-M. Exploring the Intercultural Identity of Slovak-Roma Schoolchildren in the UK // Вестник Российского университета дружбы народов. Серия: Лингвистика. 2017. Т. 21. № 2. С. $282-304$.

\section{Сведения об авторах:}

Лаура Хриниевич, магистр прикладной лингвистики (Лондонский университет, Великобритания), руководитель программы “Key Stage 5”. Сфера научных интересов: глобализация английского языка и проблемы межкультурной идентичности. Контактная информаџия: e-mail: laurahryniewicz@hotmail.com

Жан-Марк Деваеле, доктор, профессор кафедры прикладной лингвистики и коммуникации Лондонского университета, Президент Международной ассоциации мультилингвизма, главный редактор международного журнала Bilingual Education and Bilingualism, член редколлегии журнала Russian Journal of Linguistics. Cфера научных интересов: методика преподавания второго иностранного языка, прикладная лингвистика, психолингвистика, культурная идентичность, межкультурная коммуникация, обучение иностранному языку в аспекте межкультурной коммуникации, методика преподавания английского языка как иностранного, эмоции в языке, билингвизм, дискурс, прагматика. Контактная информация: e-mail: j.dewaele@bbk.ac.uk 